\title{
POLYMORPHIC VARIATION OF MONONUCLEOTIDE MICROSATELLITES IN HEALTHY HUMANS AND ITS IMPLICATION FOR MICROSATELLITE INSTABILITY SCREENING
}

\author{
Silvia Liliana COSSIO', Renata dos Santos COURA², Maria Cátira BORTOLINI2,3, \\ Roberto GIUGLIANI ${ }^{2,3,4}$, Patricia ASHTON-PROLLA ${ }^{2,3,4}$ and João Carlos PROLLA ${ }^{1}$
}

\begin{abstract}
Background - Colorectal cancer is the sixth most common tumor and the fifth in mortality in Brazil. Molecular markers have been associated with disease prognosis, especially in relation to therapeutic response and overall survival rates. Among these, microsatellite instability has been extensively studied. Microsatellite stability status is usually determined by comparison of normal and tumoral tissues from the same patient and instability is characterized by the difference in the PCR-amplification profile of these tissues at a given locus. Usually, a panel of five markers is used for this purpose. Two of them (BAT-25 and BAT-26) are considered monomorphic in populations of European origin. Aim - To analyse the frequency of constitutive polymorphic variation at BAT-25 and BAT-26 loci in a sample of individuals from Southern Brazil. Methods - Two-hundred and sixteen healthy and unrelated individuals were analised to assess the frequency of allelic variation at the BAT-25 and BAT-26 loci in DNA extracted from peripheral blood. Analysis was done by polymerase chain reaction - single strand conformation polymorphism (PCR-SSCP). Results - From the sample of patients studied, $7 \%$ and $6 \%$ of the patients had possible constitutive allelic variation at the BAT-25 and BAT-26 loci, respectively. Conclusions - These results indicate that significant constitutive allelic variation of these loci does occur in heterogeneous populations such as ours, and reinforce the importance of comparative studies between tumoral and corresponding normal tissue to determine microsatellite stability status and correctly identify microsatellite instability in selected populations.
\end{abstract}

HEADINGS - Colorectal neoplasms. Genomic instability. Polymorphism, genetic. Microsatellite repeats. Tumor markers, biological.

\section{INTRODUCTION}

Among tumors, colorectal cancer (CRC) is the third in frequency and the second in mortality in developed countries. In Brazil, it is the sixth most common type of cancer and the fifth in mortality ${ }^{(11)}$. Currently, the determination of disease prognosis is mainly based on clinical, pathological and morphological parameters. Molecular markers have also been associated with prognosis, especially in relation to therapeutic response and overall survival rates. Among them, microsatellite instability (MSI) has been extensively studied. It is a common finding in tissues prone to replication errors caused by a deficiency in the DNA mismatch repair system (MMR), which leads to the progressive accumulation of mutations, especially in mono- and dinucleotide microsatellites. Tumors that show microsatellite instability (MSI+) tend to be associated with better prognosis ${ }^{(3,12,14,18)}$. In addition, MSI is present in more than $90 \%$ of colorectal tumors from hereditary nonpolyposis colorectal cancer syndrome (HNPCC) patients and in only $15 \%$ of sporadic

Grant Support: CNPq, CAPES, FIPE/HCPA.

${ }^{1}$ Post-Graduate Programs in Gastroenterology and in ${ }^{2}$ Genetics and Molecular Biology, Federal University of Rio Grande do Sul (UFRGS); ${ }^{3}$ Department of Genetics, UFRGS; ${ }^{4}$ Service of Medical Genetics, Hospital de Clínicas de Porto Alegre, RS, Brazil.

Correspondence to: Dr. João Carlos Prolla - Service of Medical Genetics - Hospital de Clínicas - Rua Ramiro Barcelos 2350 - 90035-903 - Porto Alegre, RS, Brazil. E-mail: jcprolla@yahoo.com 
colorectal tumors. Therefore, MSI analysis is also an important screening tool in the differential diagnosis of hereditary CRCs. In general, microsatellite stability (MS) status is determined by the comparison between normal and tumoral tissues from the same patient and instability is characterized by the difference in the amplification profile of specific markers between these tissues. The International Workshop on Microsatellite Instability and Replication Error Repair (RER) Phenotypes in Cancer Detection and Familial Predisposition has recommended that MS status be studied through a panel of five markers: two mononucleotide (BAT-25 and BAT-26) and three dinucleotide (D2S123, D5S346 and D17S250) markers $^{(2}$ ${ }^{6}$. The presence of instability in two or more markers defines a tissue as MSI high (MSI-H), presence of instability in only one marker classifies the tissue as MSI low (MSI-L) and absence of instability in all five markers defines a tissue as microsatellite stable (MSS) ${ }^{(6)}$ The BAT-26 locus contains a 26-repeat adenine tract and is located within the fifth intron of the $h M S H 2$ gene, whereas the BAT-25 locus contains a 25-repeat thymine tract located within intron 16 of the $c$-kit oncogene. These mononucleotide markers are considered quasi-monomorphic in RER-negative tumors or normal tissue of European individuals, exhibiting little repeat size variation $(\sim 2 b p)$ or no variation at all ${ }^{(5,9)}$. Thus, analysis of only tumoral tissue without comparison with the corresponding normal tissue has been proposed and considered sufficient for instability detection in patients at risk for HNPCC by many authors ${ }^{(8,9,20)}$. In addition, since small unstable alleles can be easily distinguished from normal ones by SSCP (single strand conformation polymorphism) or sequencing, and BAT-26 is highly sensitive to detect MSI$\mathrm{H}$ colorectal tumors, some investigators have proposed that analysis of BAT-26 alone can determine MS status in CRCs with greater than $99 \%$ accuracy $^{(2,4,6,7,19)}$. Therefore, many published reports have determined MS status using only tumoral tissue and the two markers BAT-25 and BAT-26 instead of the panel of 5 markers originally recommended by the National Cancer Institute $(\mathrm{NCI})^{(9,10,20)}$. Recently, PYATT et al. ${ }^{(13)}$ showed a high frequency of allelic variation at the BAT-25 and BAT-26 loci in a sample of African-American individuals, suggesting that similar variations may be encountered in other populations. Most importantly, this observation reinforced the concern with the accuracy of the analysis when only tumoral tissue is used to determine MS status. Finally, a study of MSI in endometrial adenocarcinomas suggested a polymorphic profile of BAT- 25 and BAT-26 ${ }^{(19)}$. Therefore, allelic variation of these markers in specific populations should be determined before a decision is made on the most reliable clinical protocol for MSI screening. Little has been published on MS status in sporadic and hereditary $\mathrm{CRC}$ in Brazilian patients and healthy individuals ${ }^{(7)}$.

The present study reports the frequency of individuals showing constitutive polymorphic variation at the BAT-25 and BAT-26 loci in a sample of healthy individuals from the southernmost state of Brazil, Rio Grande do Sul.

\section{METHODS}

Two-hundred and sixteen healthy and unrelated individuals from Rio Grande do Sul, Brazil, were studied anonymously. The study was approved by the institutional review board and associated ethics committee. DNA was extracted from peripheral blood by a standard salting-out procedure. Screening for constitutive polymorphic variation at the BAT-25 and BAT-26 loci was performed by PCRSSCP as described previously ${ }^{(6,10)}$. All samples were compared to a normal control (WT size) and all those exhibiting a different size were considered allelic variants.

\section{RESULTS}

All 216 samples were successfully amplified for BAT 26 and 215, were amplified for BAT 25. Fifteen (7\%) and $13(6 \%)$ individuals showed variant alleles at the BAT-25 and BAT-26 loci, respectively. Only one individual $(0.5 \%)$ showed simultaneous allelic variation at both loci. Figure 1 depicts a typical SSCP mini-gel, where samples homozygous for the usual sized-alleles and allelic variants of BAT-25 and BAT-26 can be seen.

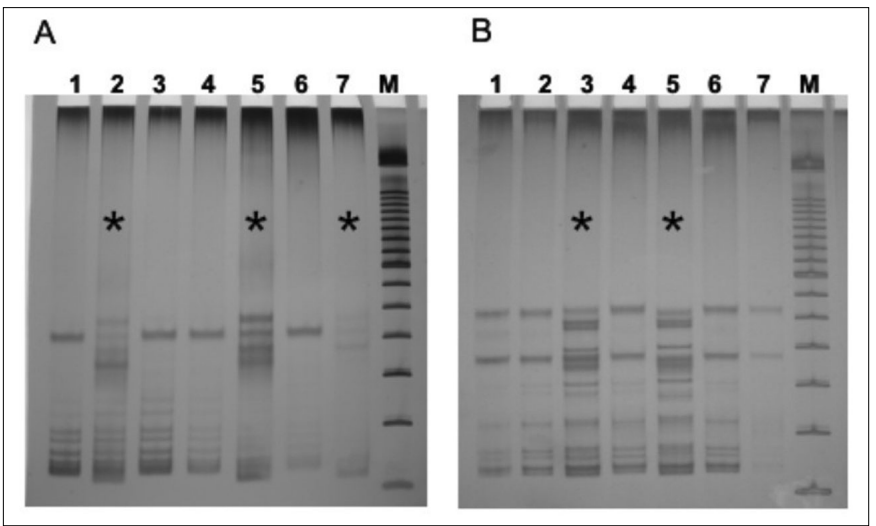

FIGURE 1. SSCP results of PCR-amplified sequences from lymphocyte DNA. A) BAT-26 amplification products: Lanes 1, 3, 4, and 6 depict the allelic pattern of fragments containing the usual 26 adenine repeats (so called common or 'large' allele); lanes 2, 5 and 7 show a variant pattern (asterisks). B) BAT-25 amplification products: Lanes 1, 2, 4, 6 and 7 depict the pattern of o fragments containing the usual 20 fragments containing the usual 25 thymine repeats; lanes 3 and 5 show a variant pattern (asterisks). $\mathrm{M}=100$ bp ladder.

\section{DISCUSSION}

MSI analysis is an important tool in the study of colorectal tumors, and has been extensively used as a screening test to identify patients with the hereditary colorectal syndrome HNPCC. Therefore, a standard panel of five microsatellite markers was established by the International Collaborative Group in HNPCC and by the NCI (USA) for this purpose ${ }^{(5)}$. The frequency of polymorphic variation at these loci has been established in Europeans, Asians and African-Americans, but little is known about its behavior in the Brazilian population ${ }^{(2,6,15)}$. The International Workshop of Microsatellite Instability and RER phenotypes in Cancer Detection and Familiar Predisposition recommended that all 
studies that include BAT-26 in the analysis of MSI should compare its pattern in normal and tumoral tissue, since this marker can show a different allelic profile (i.e. constitutional polymorphism) according to the ethnical background of the population under study ${ }^{(2,16)}$. Despite this recommendation, however, the majority of studies that have used BAT-25 and BAT-26 in CRC, including studies with Brazilian individuals, consider these two markers monomorphic and do not compare the amplification profile of tumoral and normal tissue of the same individual to determine MSI. Failure to do so may constitute an important confusion factor if the population studied is heterogeneous and indeed polymorphic at these loci, leading to misclassification of the tumor and ultimately to inappropriate management of the patient. There are several evidences in the literature that suggest that BAT-26 has considerable allelic variation ${ }^{(2,17)}$.

PYATT et al. ${ }^{(13)}$, in a populational study with 103 African American individuals, reported allelic variation of $12.6 \%$ and $18.4 \%$ in BAT-26 and BAT-25, respectively. Simultaneous allelic variation at both loci was observed in $2.9 \%$ of individuals. Finally,
ALAZZOUZI et al. ${ }^{(1)}$ described that the BAT-26 repetitive region ranges in size from 21 to 27 adenines in healthy individuals.

The present study identified possible BAT- 25 and BAT-26 variant alleles in a significant proportion of healthy individuals. If a tumor sample of such individual would be analysed for MSI without analysis of the normal corresponding tissue, this constitutive variant could be misclassified as MSI. Our results reinforce the need for the comparative analysis between normal and tumoral tissue for MSS determination to avoid false-positive results in HNPCC screening in certain populations. They also suggest that allelic variation at these loci is common in the heterogeneous Brazilian population.

\section{ACKNOWLEDGEMENTS}

Dr. Patricia Ashton-Prolla received a grant from CAPES, Brazil (Protocol \#202/03-7). Dr. Renata dos Santos Coura received a fellowship from CNPq, Brazil. This work was also supported by a grant from FIPE, Hospital de Clínicas de Porto Alegre, Brazil.

Cossio SL, Coura RS, Bortolini MC, Giugliani R, Ashton-Prolla P, Prolla JC. Variação polimórfica de microssatélites mononucleotídicos em indivíduos normais e sua implicação no rastreamento de instabilidade de microssatélites. Arq Gastroenterol. 2007;44(1):64-7.

RESUMO - Racional - No Brasil, o câncer colorretal é o sexto tumor em freqüência e o quinto em mortalidade. Marcadores moleculares têm sido associados com o prognóstico da doença, especialmente em relação à resposta terapêutica e taxa de sobrevida. Dentre eles, a instabilidade de microssatélites tem sido amplamente estudada. O estado de instabilidade de microssatélites é usualmente determinado pela comparação entre tecido tumoral e tecido normal correspondente de um mesmo paciente e a instabilidade se caracteriza pela diferença no perfil do produto de amplificação por PCR destes tecidos em um determinado locus. Usualmente, é utilizado um painel de cinco marcadores para este propósito. Dois deles (BAT-25 e BAT-26) são considerados monomórficos em populações de origem européia. Objetivo - Analisar a freqüência de variação constitutiva nos loci BAT-25 e BAT-26 em amostra de indivíduos do sul do Brasil. Métodos - Duzentos e dezesseis indivíduos saudáveis e não relacionados foram analisados para determinar a freqüência de variação alélica nestes loci. O rastreamento de variantes alélicas foi feito por "polymerase chain reaction - single strand conformation polymorphism" (PCR-SSCP). Resultados - Observou-se possível variação alélica constitutiva em 7\% e 6\% dos pacientes nos loci BAT-25 e BAT-26, respectivamente. Conclusão - Estes resultados indicam que há significativa variação alélica constitucional nos loci BAT-25 e BAT-26 em grupos selecionados, como nesta amostra de indivíduos brasileiros, e reforça a importância de estudos comparativos entre tecido tumoral e o tecido normal correspondente para identificar instabilidade de microssatélites em populações determinadas.

DESCRITORES - Neoplasias colorretais. Instabilidade genômica. Polimorfismo genético. Repetições de microssatélites. Marcadores biológicos de tumor. 


\section{REFERENCES}

1. Alazzouzi H, Domingo E, González S, Blanco I, Armengol M, Espin E, Plaja A, Schwartz S, Capella G, Schwartz S Jr. Low levels of microsatellite instability characterize MLH1 and MSH2 HNPCC carriers before tumor diagnosis. Hum Mol Gen. 2005;14:235-9.

2. Boland CR, Thibodeau SN, Hamilton SR, Sidransky D, Eshleman JR, Burt RW, Meltzer SJ, Rodriguez-Bigas MA, Fodde R, Ranzani GN, Srivastava S. A National Cancer Institute workshop on microsatellite instability for cancer detection and familial predisposition: development of international criteria for the determination of microsatellite instability in colorectal cancer. Cancer Res. 1998;58:5248-57.

3. Colombino M, Cossu A, Manca A, Dedola MF, Giordano M, Scintu F, Curci A, Avallone A, Comella G, Amoruso M, Margari A, Bonomo GM, Castriota M, Tanda F, Palmieri $\mathrm{G}$. Prevalence and prognostic role of microsatellite instability in patients with recta carcinoma. Ann Oncol. 2000;13:1447-53.

4. Coura R. Prevalência e valor prognóstico de marcadores moleculares (IMS e MutK ras) em tumores retais esporádicos [dissertação]. Porto Alegre: Universidade Federal do Rio Grande do Sul; 2005 .

5. Cravo M, Lage P, Albuquerque C, Chaves P, Claro I, Gomes T, Gaspar C, Fidalgo P, Soares J, Nobre-Leitao C. BAT-26 identifies sporadic colorectal cancers with mutato phenotype: a correlative study with clinico-pathological features and mutations in mismatch repair genes. J Pathol. 1999;188:252-7.

6. Dietmaier W, Wallinger S, Bocker T, Kullmann F, Fishel R, Rüschoff J. Diagnosti microsatellite instability: definition and correlation with mismatch repair protein expression. Cancer Res. 1997;57:4749-56.

7. Fuzikawa AK, Hadad LA, da-Cunha-Melo JR, Brasileiro-Filho G, Pena SD. Utilization of microsatellites for the analysis of genomic alterations in colorectal cancers in Brazil. Braz J Med Biol Res. 1997;30:915-21.

8. Gonzalez-Garcia I, Moreno V, Navarro M, Marti-Rague J, Marcuello E, Benasco C, Campos O, Capella G, Peinado MA. Standardized approach for microsatellite instability detection in colorectal carcinomas. J Natl Cancer Inst. 2000;92:544-9.

9. Hoang J-M, Cottu PH, Thuille B, Salmon RJ, Thomas G, Hamelin R. BAT-26, an indicator of the replication error phenotype in colorectal cancers and cell lines. Cancer Res. 1997;57:300-3.

10. Iacopetta B, Hamelin R. Rapid and nonisotopic SSCP-based analysis of the BAT-26 mononucleotide repeat for identification of the replication error phenotype in human cancers. Hum Mutat. 1998;12:355-60.
11. Instituto Nacional do Câncer. Coordenação de Prevenção e Vigilância. A situação do câncer no Brasil. Rio de Janeiro, INCA, 2006. 119p.

12. Popat S, Hubner R, Houlston RS. Systematic review of microsatellite instability and colorectal cancer prognosis. J Clin Oncol. 2005;23:609-18.

13. Pyatt R, Chadwick RB, Johnson CK, Adebamowo C, de la Chapelle A, Prior TW. Polymorphic variation at the BAT-25 and BAT-26 loci in individuals of African origin. Implications for microsatellite instability testing. Am J Pathol. 1999;155:349-53.

14. Raut CP, Pawlik TM, Rodriguez-Bigas MA. Clinicopathological features in colorectal cancer patients with microsatellite instability. Mutat Res. 2004;568:275-82.

15. Salzano FM, Bortolini MC. Evolution and genetics of Latin American populations. Cambridge: Cambridge University Press; 2002.

16. Umar A, Boland CR, Terdiman JP, Syngal S, de la Chapelle A, Ruschoff J, Fishel R, Lindor NM, Burgart LJ, Hamelin R, Hamilton SR, Hiatt RA, Jass J, Lindblom A, Lynch HT, Peltomaki P, Ramsey SD, Rodriguez-Bigas MA, Vasen HF, Hawk ET, Barrett JC, Freedman AN, Srivastava S. Revised Bethesda guidelines for hereditary nonpolyposis colorectal cancer (Lynch syndrome) and microsatellite instability. J Natl Cancer Inst. 2004;96:261-8

17. Weber TK, Chin HM, Rodriguez-Bigas M, Keitz B, Gilligan R, O’Malley L, Urf E, Diba N, Pazik J, Petrelli NJ. Novel hMLH1 and hMSH2 germline mutations in African Americans with colorectal cancer. JAMA. 1999;281:2316-20.

18. Wright CM, Dent OF, Barker M, Newland RC, Chapuis PH, Bokey EL, Young JP, Leggett BA, Jass JR, Macdonald GA. Prognostic significance of extensive microsatellite instability in sporadic clinicopathological stage C colorectal cancer. Br J Surg. 2000;87:1197-202.

19. Yu H-JA, Lin KM, Ota DM, Lynch HT. Hereditary nonpolyposis colorectal cancer: preventive management. Cancer Treat Rev. 2003;29:461-70.

20. Zhou XP, Hoang JM, Li YJ, Seruca R, Carneiro F, Sobrinho-Simoes M, Lothe RA, Gleeson CM, Russell SE, Muzeau F, Flejou JF, Hoang-Xuan K, Lidereau R, Thomas G, Hamelin R. Determination of the replication error phenotype in human tumors without the requirement for matching normal DNA by analysis of mononucleotide repeat microsatellites. Genes Chrom Cancer. 1998;21:101-7. 